\title{
UDC 006.034:504.06
}

\section{RECOMMENDATIONS FOR DESIGNING CELLULAR WALL POLYETHYLENE PIPES PLACED IN THE SOIL}

\author{
Roman Hromyak ${ }^{1}$; Marian Dorosh ${ }^{2}$;Mykola Stashchuk ${ }^{2}$ \\ ${ }^{1}$ Ternopil Ivan Puluj National Technical University, Ternopil, Ukraine \\ ${ }^{2}$ Karpenko Physico-Mechanical Institute of the National Academy of Sciences \\ of Ukraine, Lviv, Ukraine
}

Summary. Information about various Ukrainian and international national standards in the field of design and installation of polymer pipes with hollow walls is given. The strength of cellular wall polyethylene pipes placed in the soil is calculated. The choice of the calculation formula for determination of relative pipe deflection depending on the features of its operation is substantiated. The critical deflection of such structures on this basis is determined, therefore, it is recommended to calculate the strength of the cellular pipes placed in the soil according to the size of deflection, which should not exceed the critical value. deflection.

Key words: cellular polyethylene pipes, design, strength calculation, ring stiffness, relative pipe

Problem setting. Water drain and water supply engineering systems and other pipeline systems without which we cannot imagine appropriate functioning of modern society are of key importance among all engineering facilities. A considerable part of such systems have exhausted their potential and require reconstruction. Thus the problem of functional and effective means of new pipeline systems construction and reconstruction of existing ones occurs. In this regard the use of plastic pipes for engineering systems fully confirm with the set problem. Such pipes have many advantages in comparison with metal ones. Besides while in operation in different environments the functional capabilities of polymer pipes are wider. However polymer pipe constructions of large diameters with the solid section of the wall do not provide optimal mass capacity. For this reason lighter constructions with hollow walls are used. One of the versions of such structures is polymer thin-walled products with pipe-like profile of the wall (Fig. 1, 2).
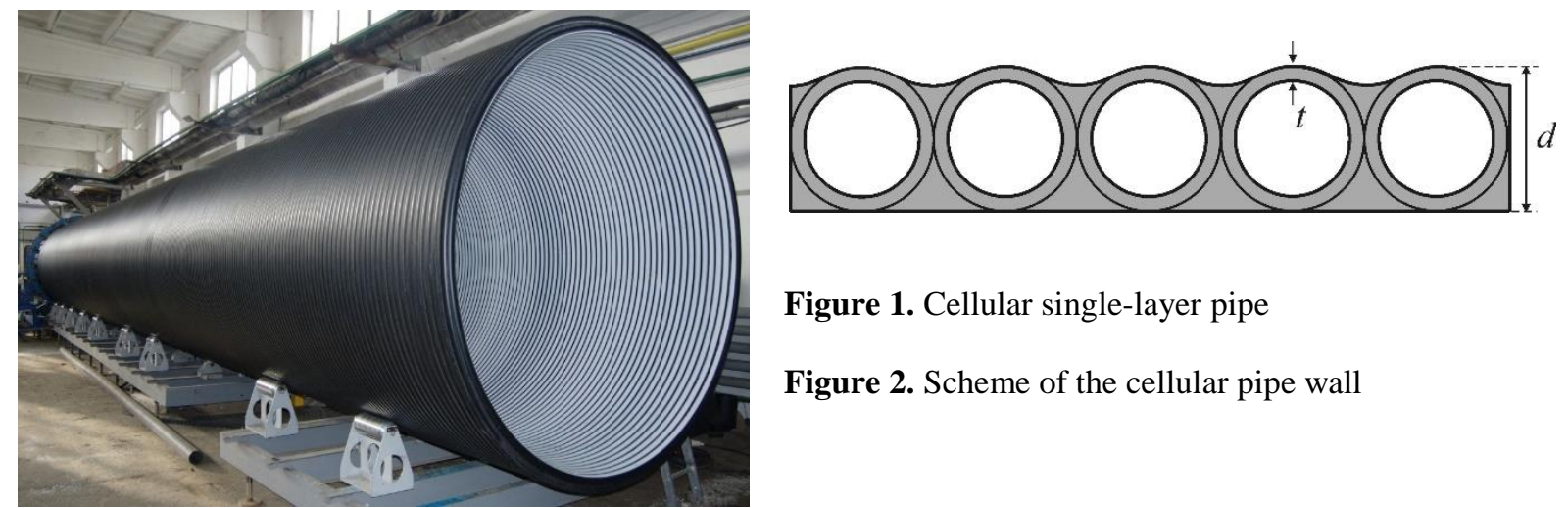

Figure 1. Cellular single-layer pipe

Figure 2. Scheme of the cellular pipe wall

They are called cellular [1]. Cells production technology is continuous process of winding on the special drum-type device of water supply polyethylene pipes with diameter $20 \div 110 \mathrm{~mm}$ with the simultaneous extrusion welding between the windings. Cellular pipe constructions are made of PE-80 and 100 polyethylene. Cells are mainly used for construction 
of low-pressure industrial drain and sewerage systems as well as for various mines, shafts and tanks.

Analysis of the known research results. Cellular pipe constructions are placed mainly in the soil where they are subjected to its steady load. That is why while designing such pipeline systems the calculation of strength providing their reliable operation is of high priority. At the same time suggestions of calculation and design of polymer pipeline systems with structured walls and cells in particular in listed above regulatory documents [2-8] are not sufficiently specified. Thus according to $[2,4]$ the strength calculation of pipelines for external sewerage system should be carried out according to the methods given in this papers. These methods have general character and are based on deformation criterion mainly concerned with pipes having solid walls and it is hardly adapted to the pipes with structured wall. At the same time in [2] while calculating pipeline strength the use of the pipes producers software package is acceptable. Standard [5] does not determine specific rules for calculation of plastic pipeline system strength.

As for worldwide standards in the field of design of polymer pipeline systems in soil, their strength is estimated chiefly according to the vertical diameter reduction value (deflection). Properly speaking the deflection itself does not directly deal with the construction edge state but existing large deflections indicate sufficient deformations in the construction wall resulting in capacity loss. The pipe deflection is also very easy to be checked.

The overwhelming majority of equations for determination of pipe deflection is represented in Spengler's formula as follows [11, 12]:

$$
\frac{\Delta}{D}=\frac{a q}{b S_{n}+c S_{s}}
$$

where $\Delta$ - being pipe deflection;

$D$ - being pipe mean diameter;

$q$ - being load intensity caused by the weight of the soil located above the pipe;

$S_{n}$ - being pipe stiffness specified as ring $[2,4]$;

$S_{s}$ - being soil stiffness;

$a, b, c-$ of steel.

The simplest method of load intensity determination $q$ provides assigning vertical pressure of the soil filling uniformly distributed along the trench width and relatively equals [13]

$$
q=H \gamma
$$

where $H$ is the soil filling height, $\gamma$ is the soil specific weight. The other methods of calculation of the active soil pressure on the pipe are based on Martson's theory [14]. He assumed that friction planes were formed along the trench walls effected by friction forces taking up the part of filling weight. According to Martson's theory $[15,16]$ the value of pressure on the pipe is lower than that calculated due to formula (2). Assuming the set of suppositions and simplifications while determining the active pressure according to Martson's theory indicated for example in [15], the vertical load on the pipe from the soil is as follows:

$$
q=V H \gamma,
$$

where coefficient $V<1$. There is no clear choice of parameter $V[15,17,18]$

Theoretically the ring stiffness is calculated by formula [2]: 


$$
S_{n}=\frac{E I}{D^{3}}
$$

where $E$ is the elasticity modulus of the pipe material; $I$ is the inertia moment of the pipe wall profile on its length unit.

As a rule the soil stiffness is assumed as the soil secant modulus $E_{s}[15,19]$. The values $a, b, c$ in Spengler's formulas (1) are also different for various worldwide standards. The most widely used formulae for relative deflection determination are given in table 1.

Table 1

Basic calculation formulas for the determination of the underground pipelines deflection [20]

\begin{tabular}{|c|c|c|c|c|c|}
\hline $\begin{array}{c}\text { National } \\
\text { construct } \\
\text { ion rules }\end{array}$ & Russian & English & French & German & Swedish \\
\hline$\frac{\Delta}{D}$ & $\frac{0,11 q}{8 S_{n}+0,06 E_{s}^{\prime}}$ & $\frac{0,1 q}{8 S_{n}+0,06 E_{s}^{\prime}}$ & $\frac{0,083 q}{16 S_{n}+0,244 E_{s}^{\prime}}$ & $\frac{0,1 q}{16 S_{n}+0,08 E_{s}^{\prime}}$ & $\frac{0,083 q}{16 S_{n}+0,122 E_{s}^{\prime}}$ \\
\hline
\end{tabular}

The relative deflection $\Delta / D$ is limited by the critical value for providing different safety objectives including: boundary deformation or bending stress, avoiding local or general durability loss. The deflection less than critical one ensures avoiding of the loss of construction capability. Different limitations for polymer pipe deflection are suggested. The typical suggestions of deflection limits from internal diameter in per cent are as follows:

- $8 \%$ - deflection during design [21];

- $8 \%$ - construction standard for plastic pipes according to CEN [22, 23];

- $6 \%$ - German construction standard ATV;

- $6 \%$ - after 12 months [24];

- 5\% - after construction [24];

- $5 \%$ - for limitation of global durability loss [25].

The results of full-scale investigations of polypropylene pipes with structured walls located in the soil are given in paper [26]. The results indicate that after 1 year of operation the maximum deformation of all pipes was less than $5 \%$.

The discussion concerning the determination of calculating deflection shape and critical value setting is not completed. Hence the choice of adequate calculation formula for deflection and determination of critical deflection is necessary for calculation of cellular pipe strength.

Key calculation formulas for cellular pipe strength determination. To determine which of the formulas given in table 1 is the most adequate for cellular pipes we used the following calculation scheme. The cellular tube is calculated for two load schemes. The first scheme deals with vertical force with intensity $q$ taking into account contact soil pressure $\eta$. The second scheme (Fig. 3b) suggests pipe sinking into the soil. The contact soil pressure is given in accordance with Winkler's type model considering ,rebuffless“ areas [27]. 

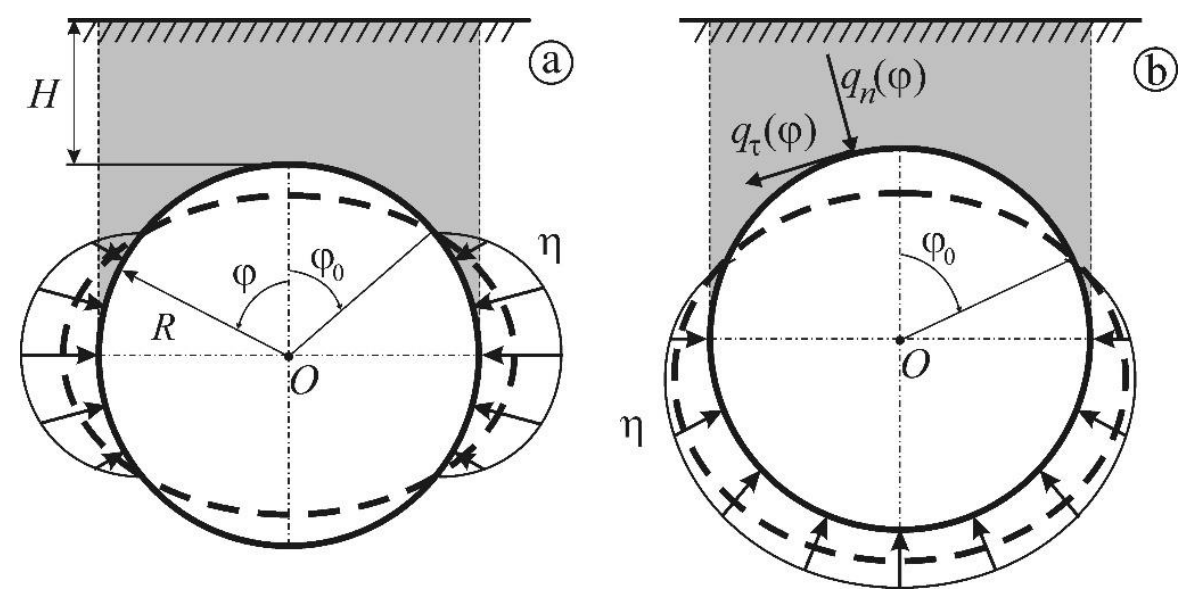

Figure 3. Scheme of cellular pipe loading (cross section): with rigid base (a); sinking into the soil (b)

The calculation of stress-strain state of cellular pipes according to the given load schemes was performed in $[28,29]$. The researches resulted in possibility to choose and transfer the standards of polyethylene pipes design with solid walls to the pipes with hollow structure. For load schemes of the cellular construction influenced by the soil (Fig. 3) the change of relative deflections (vertical diameter reduction) of the cellular pipe $\Delta / D \cdot 100 \%$ (solid lines) was calculated depending on soil secant modulus $E_{s}^{\prime}$. The values $q=26 \mathrm{kPa}$ and ring stiffness $S_{n}=2 \mathrm{kPa}$ (Fig. 4a) and $S_{n}=4 \mathrm{kPa}$ (Fig. 4b) were used in calculations. The results given in Fig. 4 were compared with the deflection calculations obtained and developed in accordance with the worldwide construction standards (Russian, German and Swedish according to Table 1) for solid polyethylene pipes (dot line). Thus curve 2 conforms with deflection calculations according to Russian construction standards of underground pipelines design (Table 1); curve 3 - German construction standard; curve 4 - Swedish one and formula.
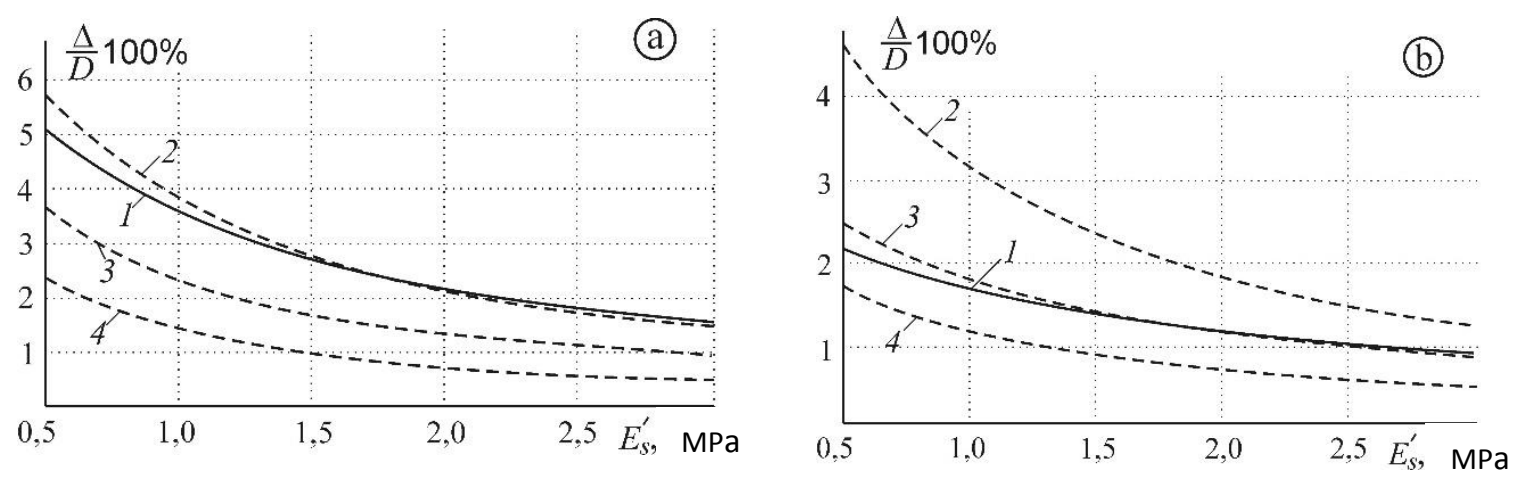

Figure 4. Dependence of relative deflection $\Delta / D \cdot 100 \%$ of long cellular pipe on the soil secant modulus $E_{s}^{\prime}$ : $\mathrm{a}$ - calculateons for the first load scheme; $\mathrm{b}$ - for the second one.

It is found that for the first load scheme (see Fig. 4a) the largest compliance is with Russian standard but for the second one (see Fig. 4b) - with German.

To determine the critical deflection of plastic pipes two calculation criteria are usually used [15]:

- providing permissible stresses: $\sigma \leq \sigma_{c r}$;

- providing permissible deformations: $\varepsilon \leq \varepsilon_{c r}$.

The pipes made of thermoplastic materials, polyethylene for example, are often calculated taking into account permissible stresses, i.e. according to the first criterion. The 
investigations of polyethylene pipes under the influence of internal hydrostatic pressure make it possible to develop international standards [30, 31]. Permissible loads on investigated constructions can be determined if:

$$
\max \sigma \leq M R S,
$$

where $\sigma$ is ring load in the hollow (cellular) pipe wall, $M R S$ is minimum long duration strength [30, 31], i.e $M R S$ - strengths, resulting in extrapolation of the results of polyethylene pipes testing on strengths to internal hydrostatic pressure for 50 years service time. Polyethylenes of PE-80 and PE-100 types have $M R S=8 \mathrm{MPa}$ and $10 \mathrm{MPa}$ relatively.

Applying theoretical results for estimation of the cellular pipes strain-stress state [28], on the basis of criterion (3) we defined critical deflections for cellular pipe depending on soil stiffness and pipe ring stiffness (Fig. 5).

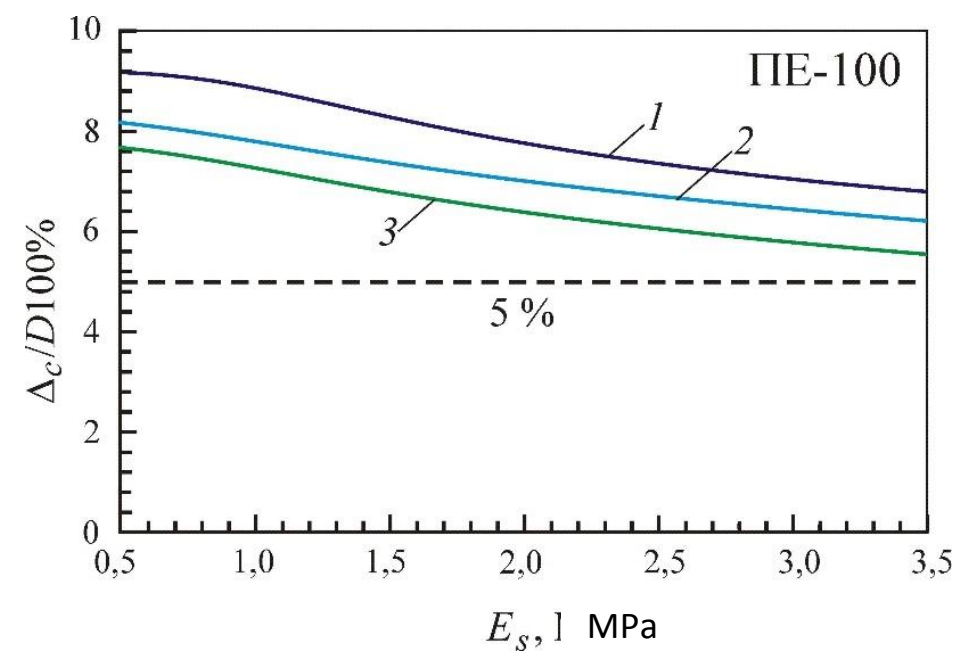

Figure 5. Dependence of critical deflection on the soil secant modulus: 1 - ring stiffness $S_{n}=2 \mathrm{kPa} ; 2-S_{n}=4 \mathrm{kPa} ; 3-S_{n}=8 \mathrm{kPa}$

Due to the results shown in Fig. 5 we can give recommendations for determination of reliable service period of polyethylene pipes with hollow (cellular) wall structure. In order to do this it is necessary to perform the following inequations:

If we take polyethylene of PE-100 type, then

$$
\frac{\Delta}{D} 100 \% \leq 5 \%,
$$

In case with ПЕ-80 type providing

$$
\frac{\Delta}{D} 100 \% \leq 4 \%
$$

The deflection of the cellular pipe is defined by formula

$$
\frac{\Delta}{D}=\frac{0,11 q}{8 S_{n}+0,06 E_{s}^{\prime}}
$$

Conforming with Russian construction standard.

It is evident from formulas (4) - (6) analysis that the strength of cellular pipes located 
in soil considerably depends on the soil type and its firming.

Conclusions. The influence of soil on strain-stressed state of polyethylene pipes with hollow wall structure is investigated. It is determined that in order to calculate deflections it is necessary to apply Russian standard in case of rigid trench base. In case of soft soil settlement the calculation and design of pipes should be done in accordance with German construction standard. Hence the critical value of relative deflection of polyethylene pipe with hollow wall structure is $5 \%$ for polyethylene of PE-100 and 4\% for PE-80 type.

\section{References}

1. Korporatsyya „Эnerhoresurs-ynvest“ predstavlyaet novuyu tekhnolohyyu proyzvodstva krupnohabarytnukh polymernukh yzdelyy s pustoteloy (sotovoy) konstruktsyey stinky. Polymernue trubu, 2007 , no. $2-3$, pp. $6-7$.

2. DSTU-N B V.2.5-40:2009. Proektuvannya ta montazh merezh vodopostachannya ta kanalizatsiyi $z$ plastykovykh trub. Vved. 21.12.2009.

3. SP 40-101-96 Proektyrovanye y montazh truboprovodov yz polypropylena „Randomsopolymer“.

4. SP 40-102-2000 Proektyrovanye y montazh truboprovodov system vodosnabzhenyya y kanalyzatsyy yz polymernukh materyalov. Obshchye trebovanyya. Vved. 16.08.2000.

5. DSTU B V.2.5-32:2007 Truby beznapirni $\mathrm{z}$ polipropilenu, polietylenu, neplastyfikovanoho polivinilkhlorydu ta fasonni vyroby do nykh dlya zovnishnikh merezh kanalizatsiyi budynkiv i sporud ta kabel'noyi kanalizatsiyi. Tekhnichni umovy.

6. Pr EN 13476-1: 2002 Plastics piping systems for non-pressure underground drainage and sewerage Unplasticized polyvinyl chloride (PVC-U), Polypropylene (PP) and Polyethylene (PE). Part 1: Requirements for pipes, fittings and the system.

7. HOST R 54475-2011 Trubu polymernue so strukturyrovannoy stenkoy y fasonnue chasty k nym dlya system naruzhnoy kanalyzatsyy. Tekhnycheskye uslovyya.

8. EN 13476-1:2007 Plastics piping systems for non-pressure underground drainage and sewerage. Structured-wall piping systems of unplasticized polyvinyl chloride. (PVC-U), polypropylene (PP) and polyethylene (PE). Part 1: General requirements and performance characteristics.

9. EN 13476-2:2007 Plastics piping systems for non-pressure underground drainage and sewerage. Structured-wall piping systems of unplasticized polyvinyl chloride. (PVC-U), polypropylene (PP) and polyethylene (PE). Part 2: Specifications for pipes and fittings with smooth internal and external surface and the system, Type A.

10.EN 13476-3:2009 Plastics piping systems for non-pressure underground drainage and sewerage. Structured-wall piping systems of unplasticized polyvinyl chloride. (PVC-U), polypropylene (PP) and polyethylene (PE). Part 3: Specifications for pipes and fittings with smooth internal and profiled external surface and the system, Type B.

11. Spangler M.G. The Structural Design of Flexible Pipe Culverts, M.G. Spangler. Iowa Engineering Experiment Station Bulletin 153. Iowa State University. Ames, 1941.

12. Watkins R.K. Some characteristics of the modulus of passive resistance of soil, R.K. Watkins, M.G. Spangler. Highway Research Record 37. Washington, D.C., 1958, pp. 389 - 397.

13. Kleyn H.K. Raschet podzemnыkh truboprovodov, H.K. Kleyn. M.: Stroyyzdat, 1969, 240 p.

14. Marston A. The theory of loads on pipes in ditches and tests of cement and clay drain tile and sewer pipe, A. Marston, A. Anderson. Iowa Engineering Experiment Station, Bull. 31, 1913, 181 p.

15. McGrath T.J. NCHRP Report 631: Updated test and design methods for thermoplastic drainage pipe, T.J. McGrath, I.D. Moore, G.Y. Hsuan. Washington, D.C.: Transportation Research Board, 2009.

16. Emel'yanov L.M. O raschete podzemnukh trub po teoryy upruhosty, L.M. Emel'yanov. Stroyt. mekhanyka y raschet sooruzhenyy, 1961, 11, pp. $32-37$.

17. Moser A.P. The structural performance of buried profile-wall pipe and the influence of pipe wall geometry, A.P. Moser. Submitted for review to the Transportation research board, July 29, 1997. Washington, D.C., 1997, pp. $123-134$.

18. McGrath T.J. Calculating loads on buried culverts based on pipe hoop stiffness, T.J. McGrath. Transportation Research Record 1656 (July, 1999). Washington, D.C., 1999, pp. 73 - 79.

19. Molin J. Long term deflection of buried plastic sewer pipes, J. Molin. Int. Conf. Advances in Underground Pipeline Engineering. Madison, 1985, pp. 263 - 277.

20. Shvabauэr V.V. Raschet podzemnoho truboprovoda yz termoplastov, V.V. Shvabauэr, Y.V. Hvozdev. Polymernue trubu. Ukrayna, 2007, no. 3, pp. $52-56$.

21. Miles R.W. Integrated design procedure for flexible pipe, R.W. Miles, B.J. Schrock. Pipelines in the constructed environment. Reston, VA, 1998, pp. 125 - 131.

22. CEN, Proposed general concept for searching a „Unified calculation method for buried pipes, CEN/TC 164/165/JWG1 N96E, European Committee for Standardization, Brussels (Belgium), 1992. 
23. CEN, Preliminary draft, annex to EN1295-2, piping pystems - Structural design of buried pipelines (Common CEN Method), CEN/TC 164/165/JWG1 N214E, European Committee for Standardization, Brussels (Belgium), 1999.

24. Structural performance of profile-wall drainage pipe-stiffness requirements contrasted with results of laboratory field tests, C.D. Rogers, P.R. Fleming, M.W. Loefpky, E. Faragher. Transportation research record 1514, Transportation Research Board, Washington, D.C., 1995, 486 p.

25. Prevost R.C. Basics of flexible pipe structural design, R.C. Prevost, K.K. Kienow. J. of Transportation Engng. 1994, 120, no. 4, pp. $652-671$.

26. Hoppe E.J. Evaluation of Polypropylene Drainage Pipe, E.J. Hoppe. Final Report VCTIR 11-R14, http://www.virginiadot.org/vtrc/main/online_reports/pdf/11-r14.pdf.

27. Vynohradov S.V. Raschet podzemnыkh truboprovodov na vneshnye nahruzky, S.V. Vynohradov. M.: Stroyyzdat, 1980, $135 \mathrm{p}$.

28. Stashchuk M.H. Calculation of large-size polyethylene pipes with hollow walls, M.H. Stashchuk, M.I. Dorosh. Materials Science, 2013, vol. 48, no. 4, pp. $456-463$.

29. Stashchuk M.H. Calculation of buried structural honeycomb polymer piping components, M.H. Stashchuk, M.I. Dorosh. Strength of Materials, 2013, vol. 45, no. 3, pp. $351-360$.

30. ISO 12162:1995. Thermoplastics materials for pipes and fittings for pressure application. Classification and designation, Overall service (design) coefficient. Introduced 1.06.1995.

31. ISO 9080:2003. Plastic piping and ducting systems - Determination of the long-term hydrostatic strength of thermoplastics materials in pipe form by extrapolation. Introduced 19.08.2003.

\section{Список використаної літератури}

1. Корпорация «Энергоресурс-инвест» представляет новую технологию производства крупногабаритных полимерных изделий с пустотелой (сотовой) конструкцией стенки [Текст] / Полимерные трубы. - 2007. - № 2 - 3. - С. 6 - 7 .

2. ДСТУ-Н Б В.2.5-40:2009. Проектування та монтаж мереж водопостачання та каналізації 3 пластикових труб. - Введ. 21.12.2009.

3. СП 40-101-96 Проектирование и монтаж трубопроводов из полипропилена «Рандомсополимер».

4. СП 40-102-2000. Проектирование и монтаж трубопроводов систем водоснабжения и канализации из полимерных материалов. Общие требования. - Введ. 16.08.2000.

5. ДСТУ Б В.2.5-32:2007 Труби безнапірні з поліпропілену, поліетилену, непластифікованого полівінілхлориду та фасонні вироби до них для зовнішніх мереж каналізації будинків і споруд та кабельної каналізації. Технічні умови.

6. Pr EN 13476-1: 2002 Plastics piping systems for non-pressure underground drainage and sewerage Unplasticized polyvinyl chloride (PVC-U), Polypropylene (PP) and Polyethylene (PE) - Part 1: Requirements for pipes, fittings and the system.

7. ГОСТ Р 54475-2011 Трубы полимерные со структурированной стенкой и фасонные части к ним для систем наружной канализации. Технические условия.

8. EN 13476-1:2007 Plastics piping systems for non-pressure underground drainage and sewerage Structured-wall piping systems of unplasticized polyvinyl chloride) (PVC-U), polypropylene (PP) and polyethylene (PE) - Part 1: General requirements and performance characteristics.

9. EN 13476-2:2007 Plastics piping systems for non-pressure underground drainage and sewerage Structured-wall piping systems of unplasticized polyvinyl chloride) (PVC-U), polypropylene (PP) and polyethylene (PE) - Part 2: Specifications for pipes and fittings with smooth internal and external surface and the system, Type A.

10. EN 13476-3:2009 Plastics piping systems for non-pressure underground drainage and sewerage Structured-wall piping systems of unplasticized polyvinyl chloride) (PVC-U), polypropylene (PP) and polyethylene (PE) - Part 3: Specifications for pipes and fittings with smooth internal and profiled external surface and the system, Type B.

11. Spangler M.G. The Structural Design of Flexible Pipe Culverts, M.G. Spangler. Iowa Engineering Experiment Station Bulletin 153. Iowa State University. Ames. 1941.

12. Watkins R.K. Some characteristics of the modulus of passive resistance of soil, R.K. Watkins, M.G. Spangler. Highway Research Record 37. Washington, D.C., 1958, pp. 389 - 397.

13. Клейн, Г.К. Расчет подземных трубопроводов [Текст] / Г.К. Клейн. - М.: Стройиздат, 1969. - 240 с.

14. Marston A. The theory of loads on pipes in ditches and tests of cement and clay drain tile and sewer pipe, A. Marston, A. Anderson. Iowa Engineering Experiment Station, Bull. 31. 1913. 181 p.

15. McGrath T.J. NCHRP Report 631: Updated test and design methods for thermoplastic drainage pipe, T.J. McGrath, I.D. Moore, G.Y. Hsuan. Washington, D.C.: Transportation Research Board, 2009.

16. Емельянов, Л.М. О расчете подземных труб по теории упругости [Текст] / Л.М. Емельянов // Строит. механика и расчет сооружений. - 1961. - № 11. - С. $32-37$.

17. Moser A.P. The structural performance of buried profile-wall pipe and the influence of pipe wall geometry, A.P. Moser. Submitted for review to the Transportation research board, July 29, 1997. Washington, D.C., 1997, pp. $123-134$. 
18. McGrath T.J. Calculating loads on buried culverts based on pipe hoop stiffness, T.J. McGrath. Transportation Research Record 1656 (July, 1999). Washington, D.C., 1999, pp. 73 - 79.

19. Molin J. Long term deflection of buried plastic sewer pipes, J. Molin. Int. Conf. Advances in Underground Pipeline Engineering. Madison, 1985, pp. $263-277$.

20. Швабауэр, В.В. Расчет подземного трубопровода из термопластов [Текст] / В.В. Швабауэр, И.В. Гвоздев // Полимерные трубы. Украина. - 2007. - № 3. - С. 52 - 56.

21. Miles R. W. Integrated design procedure for flexible pipe, R. W. Miles, B. J. Schrock. Pipelines in the constructed environment. Reston, VA, 1998, pp. 125 - 131.

22. CEN, Proposed general concept for searching a „Unified calculation method“ for buried pipes, CEN/TC 164/165/JWG1 N96E, European Committee for Standardization, Brussels (Belgium), 1992.

23. CEN, Preliminary draft, annex to EN1295-2, piping pystems - Structural design of buried pipelines (Common CEN Method), CEN/TC 164/165/JWG1 N214E, European Committee for Standardization, Brussels (Belgium), 1999.

24. Structural performance of profile-wall drainage pipe-stiffness requirements contrasted with results of laboratory field tests, C.D. Rogers, P.R. Fleming, M.W. Loefpky, E. Faragher. Transportation research record 1514, Transportation Research Board, Washington, D.C., 1995. 486 p.

25. Prevost R.C. Basics of flexible pipe structural design, R.C. Prevost, K.K. Kienow. J. of Transportation Engng. 1994, 120, no. 4, pp. $652-671$.

26. Hoppe E.J. Evaluation of Polypropylene Drainage Pipe, E.J. Hoppe. Final Report VCTIR 11-R14, http://www.virginiadot.org/vtrc/main/online_reports/pdf/11-r14.pdf.

27. Виноградов, С.В. Расчет подземных трубопроводов на внешние нагрузки [Текст] / С.В. Виноградов. - М.: Стройиздат, 1980. - 135 с.

28. Стащук, М.Г. Розрахунок великогабаритних поліетиленових труб з порожнистою стінкою [Текст] / М.Г. Стащук, М.І. Дорош // Фіз.-хім. механіка матеріалів. - 2012. - № 4. - С. 39 - 45. (Stashchuk M.H. Calculation of large-size polyethylene pipes with hollow walls, M.H. Stashchuk, M.I. Dorosh. Materials Science, 2013. Vol. 48, no. 4, pp. 456-463).

29. Стащук, М.Г. Розрахунок стільникових полімерних трубчастих елементів конструкцій для експлуатації в грунтах [Текст] / М.Г. Стащук, М.I. Дорош // Проблемы прочности. - 2013. - № 3. pp. 135 - 147. (Stashchuk M.H. Calculation of buried structural honeycomb polymer piping components, M.H. Stashchuk, M.I. Dorosh. Strength of Materials, 2013. Vol. 45, no. , pp. 351 - 360).

30. ISO 12162:1995. Thermoplastics materials for pipes and fittings for pressure application. - Classification and designation - Overall service (design) coefficient. - Introduced 1.06.1995.

31. ISO 9080:2003. Plastic piping and ducting systems - Determination of the long-term hydrostatic strength of thermoplastics materials in pipe form by extrapolation. - Introduced 19.08.2003.

\title{
УДК 006.034:504.06
}

\section{РЕКОМЕНДАЦІЇ ПРИ ПРОЕКТУВАННІ ПОЛІЕТИЛЕНОВИХ СТІЛЬНИКОВИХ ТРУБ, ЗАГЛИБЛЕНИХ У ГРУНТ}

\author{
Роман Гром'як'; Мар'ян Дорош²; Микола Стащук² \\ ${ }^{1}$ Тернопільський національний технічний університет імені Івана Пулюя, \\ Тернопіль, Україна \\ ${ }^{2}$ Фізико-механічний інститут ім. Г.В. Карпенка НАН Украӥни, \\ Львів, Україна
}

\begin{abstract}
Резюме. Наведено інформацію про різні украйнські та міжнародні національні стандарти у сфері проектування і монтажу полімерних труб зі пустотілими стінками. Проведено розрахунок на міџність стільникових труб, укладених у трунт. Обтрунтовано вибір розрахункової формули для встановлення відносного прогину труби залежно від особливостей ї̈ експлуатації. На цій основі встановлено критичний прогин таких конструкиій. Відповідно рекомендується розрахунок на міцність стільникових труб, заглиблених у трунт, проводити за величиною прогину, щь не повинен перевищувати критичного значення.

Ключові слова: поліетиленові стільникові труби, проектування, розрахунок на міцність, кільцева жорсткість, відносний прогин труби.
\end{abstract}

Отримано 25.09.2017 